\title{
PEMBINAAN MANAJEMEN EKONOMI SYARIAH ANGGOTA KOPERASI WANITA SYARIAH AS SALAM BULUSARI TULUNGAGUNG
}

\author{
Agus Eko Sujianto \\ Institut Agama Islam Negeri (IAIN) Tulungagung; Jl. Mayor Sujadi Timur No. 46 Tulungagung; \\ Telp. (0355) 321513 \\ Program Studi Magister Ekonomi Syariah, Pascasarjana IAIN Tulungagung \\ E-mail: agusekosujianto@gmail.com
}

\begin{abstract}
Institutionally, the Sharia Cooperatives for Women (Koperasi Wanita Syariah, Ind.) in East Java were established top down based on the Minister of Home Affairs Regulation and the East Java Governor's Decree. This community service research was conducted at the Koperasi Wanita Syariah "As-Salam" of Bulusari, Tulungagung owing to the fact it is categorized as an active institution in Tulungagung. From a thorough observation, the institution has been relatively applying sharia principles in its operation, for example, by conducting wadi'ah deposit service. However, it has not applied the management of zakat yet as proofed by the fact that, in its 2017 and 2018 financial years, it did not execute zakat as the fourth pillar of Islam. The coaching of sharia management to the members of this institution is meant to become a learning medium in implementing sharia economy as one of important economic components to realize a Muslim state which spreads the blessing for all (rahmatan li al-älamin).
\end{abstract}

Keywords-Coaching, Sharia Management, Women's Cooperatives, Contextual Learning

\section{Abstrak}

Secara kelembagaan Kopwan Syariah di Jawa Timur (Jatim) berdiri secara top down yang didasarkan pada Peraturan Menteri Dalam Negeri dan Keputusan Gubernur Jatim. Lokus pengabdian ini pada Kopwan Syariah As Salam Tulungagung dengan pertimbangan bahwa Kopwan ini masuk dalam kategori Kopwan Syariah aktif di Kabupaten Tulungagung. Berdasar pengamatan, Kopwan Syariah As Salam relatif sudah menerapkan prinsip syariah misalnya dalam bentuk simpanan wadi'ah. Hanya saja belum nampak terkait manajemen zakat, dimana pada tahun buku 2017 dan 2018 Kopwan Syariah As Salam belum menjalankan rukun Islam ke empat yaitu zakat. Dengan pembinaan manajemen syariah kepada insan Kopwan Syariah As Salam Tulungagung ini diharapakan bisa menjadi media pembelajaran dalam mengimplemantasikan ekonomi syariah sebagai komponen ekonomi untuk mewujudkan negara yang rahmatan lil alamin.

Kata kunci-Pembinaan, Manajemen Syariah, Koperasi Wanita, Pembelajaran Kontekstual

\section{PENDAHULUAN}

Sebagai salah satu jenis koperasi, keberadaan Koperasi Wanita (Kopwan) Syariah di Jawa Timur sangat penting dalam mendorong perekonomian rumah tangga individu maupun rumah tangga perusahaan termasuk koperasi. Sedangkan lahirnya Kopwan Syariah di Jawa Timur didasarkan pada peraturan perundang-undangan (Peraturan Menteri Dalam Negeri Republik Indonesia Nomor 39 Tahun 2012 dan Keputusan Gubernur Jawa Timur Nomor 188/ 71 /KPTS/013/2015) bahwa koperasi syariah dibangun untuk meningkatkan perekonomian daerah khususnya untuk meningkatkan produktifitas wanita misalnya kelompok fatayat NU, aisiyah, yasinan dan majelis taklim dalam akses permodalan terhadap Lembaga Keuangan Mikro (LKM).

Hibah permodalan ini selanjutnya bukan tanpa masalah, karena dalam banyak hal terdapat kasus yang mengganggu penyaluran bantuan dari pemerintah baik pusat maupun daerah. Suswanto, et al (2013) mengemukakan bahwa hibah permodalan tanpa diikuti dengan 
pendampingan dan pembinaan manajerial pengelolanya hanya akan melahirkan permasalahan baru misalnya permasalahan ekonomi dan sosial. Secara ekonomi hibah permodalan yang mengalami kegagalan akan menimbulkan pemborosan keuangan segara, sedangkan secara sosial hibah permodalan yang mengalami kemacetan akan mengakibatkan konflik horizontal di kalangan masyarakat.

Studi ini dimaksudkan untuk mengurangi ekses-ekses negatif dari program hibah permodalan oleh pemerintah kepada kelompok wanita yang mempunyai kegiatan produktif. Dan mengingat kelompok wanita dalam bentuk Kopwan Syariah ini beranggotakan ibu-ibu yang tergabung dalam organisasi fatayat $\mathrm{NU}$, aisiyah, yasinan dan majelis taklim yang sangat terbatas kompetensinya dalam mengelola ekonomi dan akuntansi terlebih yang menerapkan prinsip-prinsip syariah maka dipandang perlu untuk memberikan penguatan pemahaman baik secara kognitif, afektif dan psikomotorik, sebagaimana dikemukakan oleh Suaidah (2017).

Pemahaman manajemen syariah dapat diimplementasikan dalam bentuk pengelolaan Kopwan Syariah yang menjunjung tinggi etika bisnis sebagaimana dikemukakan oleh Amin dan Tim PEBS FEUI (2010), bahwa etika bisnis yaitu cara-cara atau perilaku etik dalam bisnis yang dilakukan oleh manajer atau kru. Sementara itu Islam menempatkan nilai etika dalam hidup manusia di tempat yang peling tinggi, dan agama Islam diturunkan sebagai kode perilaku moral dan etika bagi kehidupan manusia. Sedangkan Nurhayati (2015) mengemukakan, pemahaman tentang akuntansi syariah diperlukan untuk mendukung kegiatan yang harus dilakukan sesuai syariah, karena tidak mungkin dapat menerapkan akuntansi yang sesuai dengan syariah jika transaksi yang akan dicatat oleh proses akuntansi tidak sesuai dengan syariah.

Salah satu contoh penerapan akuntansi syariah ini misalnya dalam bentuk zakat sebagaimana dikemukakan oleh Kusumawati (2005), bahwa dengan adanya kewajiban pembayaran zakat bagi perusahaan yang dimiliki oleh muslim maka pos zakat hasil usaha disajikan sebesar $2,5 \%$ atau $2,575 \%$ dari laba bersih. Penghitungan zakat ini dimaksudkan untuk pemerataan kesejahteraan bagi seluruh umat dan tidak bagi seholongan orang saja. Tabel berikut ini meupakan bantuk langsung dalam perhitungan laba-rugi perusahaan.

\begin{tabular}{lcc} 
Tabel 1 Perhitungan Laba-Rugi dengan Unsur Zakat \\
\hline Pendapatan: & & \\
\hline - Pendapatan Bersih & XXXX & \\
- Pendapatan Dividen & XXXX & \\
- Pendapatan Sewa & XXXX & \\
Total Pendapatan & & XXXX \\
\hline Beban: & & \\
- Harga Pokok Penjualan & XXXX & \\
- Beban Penjualan & XXXX & \\
- Beban Administrasi & XXXX & \\
- Beban Lainnya & XXXX & \\
Total Beban & & $\frac{(X X X X)}{\text { XXXX }}$ \\
Laba Bersih Kena Zakat & & $\frac{(X X X X)}{\text { Zakat }}$ \\
Laba Bersih Setelah Zakat & & XXXX \\
\hline
\end{tabular}

Penelitian terhadulu yang mengkaji tentang Kopwan Syariah di Indonesia sebagaimana dikemukakan oleh Wibowo (2010) dalam studinya menemukan bahwa masyarakat menjadi nasabah Kopwan Syariah Saraswati Kabupaten Karanganyar Jawa Tengah karena beberapa pertimbangan yaitu: promosi, sistem operasionalnya yang syariah, persyaratan administrasinya dan karena sistem bagi hasilnya. Sedangkan Ngasifudin dan Salam (2015) dalam wawancaranya dengan anggota Kopwan Baitul Mal wa Tanwil (BMT) An-Nisa Yogyakarta bahwa peningkatan partisipasi anggota dapat meningkatkan pendapatan keluarga disamping pendapatan suami mengingat banyak anggota Kopwan yang memiliki warung dan toko sehingga berdampak terhadap peningkatan kesejahteraan (fallah) keluarganya.

Kemudian Rafsanjani dan Amin (2017) menemukan bahwa Kopwan yang bergerak di bidang simpan pinjam dan pembiayaan syariah didirikan oleh anggotanya dalam rangka untuk: (1) 
mensejahterakan anggota koperasi, secara sosial bermanfaat supaya anggota terbebas dari rentenir dan terbebas dari sistem riba/bunga; (2) dalam bidang ekonomi bisa menjadi saranan dakwah dan memegang teguh sikap istiqomah, fathonah dan amanah; (3) semangat kebersamaan, sebagai implementasi ukhuwah Islamiyyah serta (4) lapangan kerja akan tumbuh dengan hadirnya pembiayaan syariah untuk-untuk usaha-usaha strategis anggota Kopwan.

Sementara itu di dunia internasional sebagaimana penelitian Harry dan Ewubare (2017), bahwa di Nigeria peran perempuan dalam koperasi memiliki hubungan yang signifikan terhadap pembangunan ekonomi. Sementara itu Koutsou, et al (2003) menjelaskan bahwa Kopwan merupakan jenis koperasi yang paling orisinal di Yunani dan bertujuan untuk meningkatkan pendapatan keluarga mereka serta untuk meningkatkan status sosial mereka. Disamping itu, partisipasi anggota Kopwan dapat memberi mereka tambahan pendapatan dan memberi mereka sebuah harga diri.

Berdasar pemikiran singkat yang diperkuat oleh teori dan penelitian terdahulu yang relevan maka metode pembinaan yang dipilih dalam program ini yaitu dengan cara ceramah yang dikombinasikan dengan model pembelajaran kontekstual (Contextual Teaching and Learning), sebagaimana dikemukakan oleh Suradin (2018) bahwa pembelajaran CTL dapat berpengaruh positif terhadap hasil belajar peserta didik.

\section{METODE}

Metode yang digunakan dalam pengabdian kepada masyarakat ini menggunakan tiga tahapan yaitu: (1) menentukan khalayak sasaran; (2) memilih metode pengabdian dan (3) menentukan tahapan kegiatan pengabdian kepada masyarakat. Pertama, menentukan khalayak sasaran yaitu anggota Kopwan Syari'ah As Salam. Kopwan ini berada di Desa Bulusari Kecamatan Kedungwaru Kabupaten Tulungagung. Status Badan Hukum koperasi diperoleh pada tanggal 28 Maret 2016 dengan nomor: 188.4/788/BH/XVI.29/115/2016. Jumlah anggota sebanyak 26 orang dengan jenis usaha simpan pinjam. Dasar pertimbangan memilih khalayak sasaran, karena menurut data Dinas Koperasi dan Usaha Mikro Kecil Menengah (UMKM) Kabupaten Tulungagung Kopwan Syari'ah As Salam ini masuk dalam kategori koperasi aktif, karena rutin menyelenggarakan rapat anggota tahunan dan memberikan laporan keuangan pada Dinas Koperasi UMKM Tulungagung.

Kedua, memilih metode pengabdian. Metode yang dipilih untuk melaksanakan Tri Dharma Perguruan Tinggi yang ketiga pengabdian kepada masyarakat ini yaitu dalam bentuk pembinaan. Pembinaan dilakukan pada seluruh anggota dengan materi pembinaan: (1) Peluang dan Tantangan Kopwan Syariah (Dahulu, Sekarang dan Yang Akan Datang); (2) Implementasi Manajemen Ekonomi Syariah dalam Tata Laksana Kopwan dan (3) Pengembangan Kelembagaan Kopwan Syariah di Tulungagung. Strategi pembinaan yang dipilih yaitu dengan metode ceramah.

Ketiga, menentukan tahapan pengabdian kepada masyarakat sebagai berikut: (1) melakukan pengamatan dengan cara pemetaan swadaya kepada Dinas Koperasi dan UMKM) Kabupaten Tulungagung dan ketua Kopwan Syariah; (2) membuat dan mendistribusikan undangan kepada anggota Kopwan Syariah: (3) melakukan pembinaan dalam bentuk ceramah dan (4) tindak lanjut. Yang dimaksud dengan tindak lanjut yaitu keberlanjutan program pengabdian kepada masyarakat, dimana output program ini yaitu publikasi ilmiah dalam bentuk jurnal terindeks. Dengan dipublishnya karya pengabdian kepada masyarakat ini diharapkan bahwa pengabdian kepada masyarakat tidak berhenti dalam bentuk kegiatan fisik atau nonfisik yang hanya dinikmati oleh mitra dampingan, tetapi juga bermanfaat bagi khalayak akademik. Publikasi ilmiah ini juga menjadi tanggung jawab akademik sebagai insan atau tenaga pendidik pada perguruan tinggi.

Sementara itu model pembinaan yang dipilih yaitu dengan mengadopsi model pembelajaran Contextual Teaching and Learning (CTL) dengan pertimbangan bahwa pendekatan ini lebih fleksibel dalam memberikan pemahaman kepada anggota Kopwan Syariah yang mayoritas berangkat dari jamaah muslimat. Jamaah muslimat ini rata-rata berpendidikan rendah atau SMA ke bawah, sehingga diperlukan ketelatenan dan kesabaran dalam melakukan pembinaan. Anggota tidak bisa dilepas begitu saja, melainkan secara perlahan mereka-mereka ini diberi pemahaman dalam berkoperasi yang berdasar syariah. Anggota tidak diharapkan untuk mencatat materi pembinaan, tetapi didasarkan pada pengalaman langsung mereka seraya diberi pembinaan 
sehingga diharapkan, para anggota tidak saja memiliki kekuatan pada aspek kognitifnya, tetapi juga afektif dan psikomotoriknya dapat terbangun.

Implementasi domain psikomotorik ini ditunjukkan dalam bentuk buku tamu dan buku anjuran instansi lain yang selalu dikerjakan oleh pengurus. Keterkaitannya dengan pendekatan CTL, para anggota, pengurus dan pengawas didorong untuk menyampaikan pengalamanya dalam mengelola Kopwan Syariah As Salam termasuk buku pokok, buku penunjang dan buku administrasi usaha. Mereka diberi kesempatan untuk menyampaikan segala sesuatu yang selama ini mereka sudah melaksanakan manajemen Kopwan sesuai petunjuk pelaksanaan dan petunjuk teknis dari Dinas Koperasi dan UMKM Kabupaten Tulungagung. Namun demikian dari segi manajemen syariah belum dipahami dengan baik oleh anggota, pengurus dan pengawas, sehingga studi ini perlu dilaksanakan sebagai pionir dalam melakukan pembinaan yang lebih besar khususnya di wilayah kerja Dinas Koperasi dan UMKM Kabupaten Tulungagung pada masa yang akan datang.

\section{Hasil}

\section{HASIL DAN DISKUSI}

Sebelum pembinaan terhadap anggota Kopwan Syariah As Salam dilaksanakan, terlebih dahulu dilakukan pemetaan swadaya yang bertujuan untuk memperolah gambaran yang jelas mengenai keberadaan Kopwan Syariah As Salam. Transek dilakukan pada Dinas Koperasi dan UMKM Kabupaten Tulungagung dan ketua Kopwan Syariah As Salam.

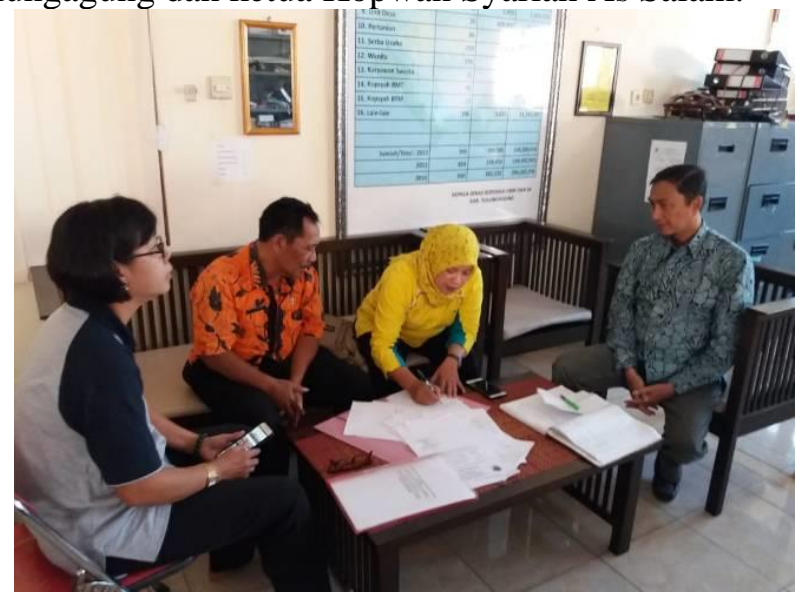

Gambar 1 Kegiatan Pemetaan Swadaya pada Dinas Koperasi dan UMKM Kabupaten Tulungagung

Gambar 1 menunjukkan kegiatan silaturahim di Dinas Koperasi dan UMKM Kabupaten Tulungagung khususnya Bidang Kelembagaan untuk memperoleh data tentang Kopwan Syariah aktif di Tulungagung pada hari Rabu, 2 Oktober 2019. Berdasar data yang didokumentasikan oleh Dinas Koperasi dan UMKM Kabupaten Tulungagung bahwa ternyata Kopwan Syariah As Salam Bulusari Tulungagung masuk dalam kategori Kopwan Syariah aktif.

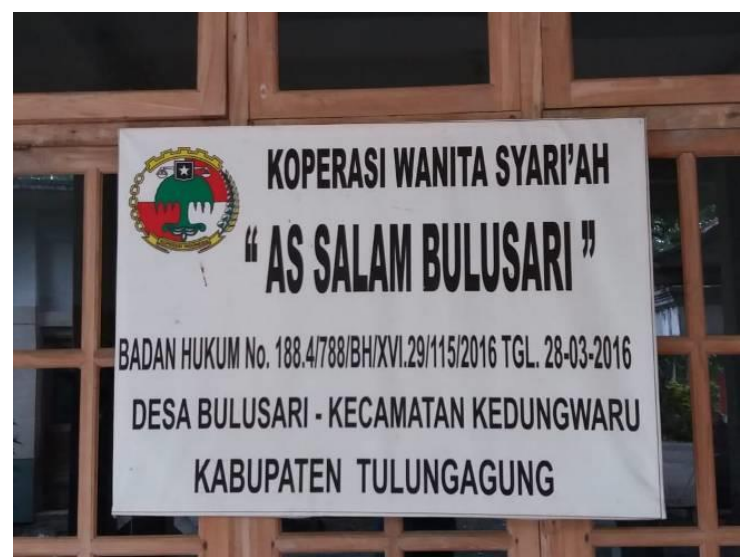

Gambar 2 Papan Nama Kopwan Syariah As Salam 
Setelah Kopwan Syariah As Salam diputuskan untuk menjadi mitra binaan, selanjutnya peneliti melakukan silaturahim dengan ketua Kopwan Syariah (Hj Umu Kulsumi) bertempat di Sekolah Menengah Pertama Negeri (SMPN) 2 Ngunut Tulungagung, tempat ibu ketua Kopwan Syariah As Salam bekerja. Kegiatan yang dilakukan pada hari Kamis, 3 Oktober 2019 ini yaitu melakukan wawancara mendalam dengan ibu Umu Kulsumi tentang Kopwan Syariah yaitu: tentang jumlah anggota, data tentang pengurus dan pelaksanaan Rapat Anggota Tahunan (RAT). Jumlah anggota Kopwan Syariah As Salam ini sebanyak 26 orang. Susunan pengurusnya yaitu: Hj Umu Kulsumi (Ketua), Masamah (Sekretaris), Yayuk Faidah (Bendahara) serta pengawas yaitu Jumiati (Koordinator) dan Purnami (anggota). Dalam kaitannya dengan RAT, pada tahun 2019 RAT dilaksanakan pada tangga 17 Maret 2019 dengan tujuan: (1) untuk membahas, mengevaluasi, menetapkan dan mengesahkan laporan pertanggung jawaban pengurus dan pengawas tahun buku 2018; (2) untuk membahas, menetapkan dan mengesahkan Rencana Kerja (RK) dan Rencana Anggaran Pendapatan Belanja (RAPB) Kopwan Syariah serta (3) penetapan pembagian Sisa Hasil Usaha (SHU). Pada RAT tahun 2019 ini dihadiri oleh perwakilan Dinas Koperasi dan UMKM Kabupaten Tulungagung, pengurus, pengawas dan seluruh anggota Kopwan Syariah As Salam Bulusari Tulungagung.

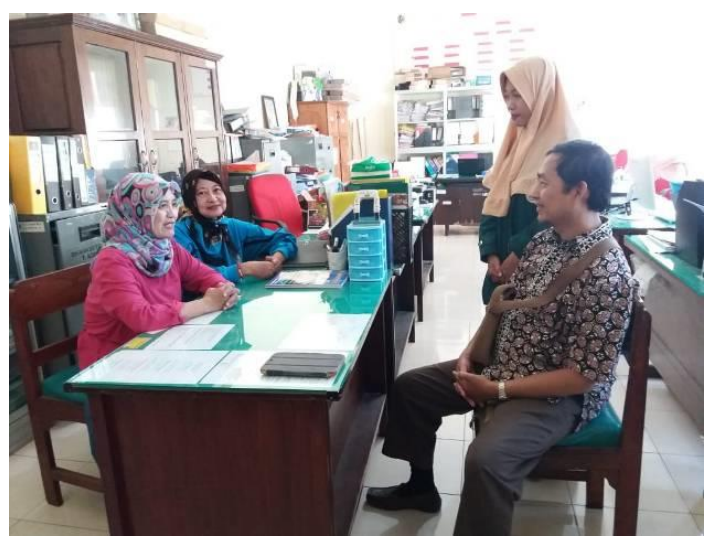

Gambar 3 Wawancara Mendalam dengan Ketua Kopwan Syariah

Pada wawancara mendalam ini peneliti juga mengemukakan tentang maksud dan tujuan yaitu ingin melakukan pengabdian kepada masyarakat melalui pembinaan manajemen syariah terhadap anggota. Kemudian ketua Kopwan Syariah As Salam meminta waktu untuk rapat pengurus membahas tentang rencana kegiatan Pembinaan Manajemen Syariah kepada Anggota Kopwan Syariah As Salam.

Berdasar hasil rapat pengurus diputuskan bahwa Kopwan Syariah As Salam bersedia menjadi mitra binaan. Undangan kepada anggota, pengurus dan pengawas dibuat oleh sekretaris dan disepakati bahwa waktu pelaksanaan pembinaan pada hari Sabtu, 12 Oktober 2019 bertempat di Masjid Bir Ali Desa Bulusari Kecamatan Kedungwaru Kabupaten Tulungagung.

Sebagaimana disebutkan di atas bahwa bentuk pembinaan dalam pengabdian ini yaitu ceramah, dengan mengangkat dua materi sederhana yaitu: implementasi manajemen syariah pada Kopwan dan sistem pembukuan atau akuntansi berbasis syariah. Kegiatan dimulai dengan melakukan registrasi dengan mengisi daftar hadir peserta, dan berdasar data, seluruh anggota menghadiri kegiatan yaitu sebanyak 25 orang.

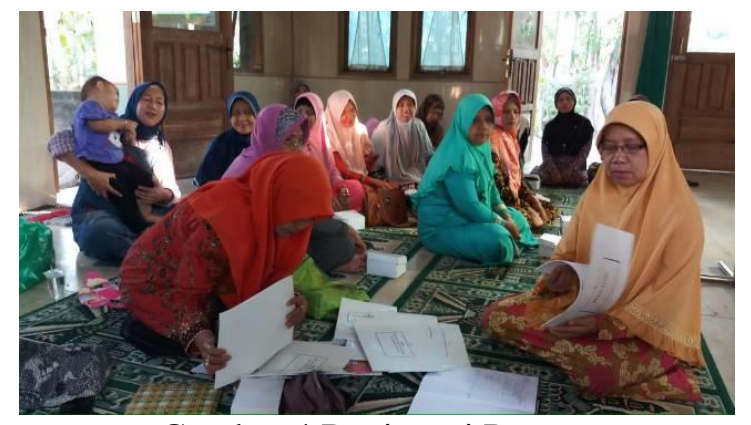

Gambar 4 Registrasi Peserta 
Setelah registrasi dilanjutkan dengan kegiatan inti yaitu pembinaan, yang pertama terkait implementasi manajemen syariah pada Kopwan. Pada aspek ini anggota diberi pemahaman bahwa bekerja itu bagian dari ibadah. Berpartisipasi aktif pada Kopwan Syariah itu merupakan kewajiban bagi anggotanya dalam pandangan koperasi, namun demikian secara syariat Islam bekerja itu merupakan ibadah yang sudah barang tentu akan membuahkan hasil yaitu keridloan Allah Subhanahu wata'ala. Para peserta sangat antusias dalam mengikuti kegiatan yang dibuktikan dengan partisipasi peserta dalam diskusi, sebagaimana dokumentasi pada gambar 5.

Yang kedua materi terkait sistem pembukuan atau akuntansi berbasis syariah. Pada aspek ini peserta diajak untuk memahami secara langsung laporan keuangan yaitu "Perhitungan SHU Desember 2017 dan 2018 Kopwan As Salam Tulungagung”. Anggota aktif berpartisipasi dalam diskusi, dan mereka baru mengetahui bahwa laporan perhitungan SHU koperasi selama ini belum sepenuhnya sesuai dengan nilai-nilai akuntansi Syariah.
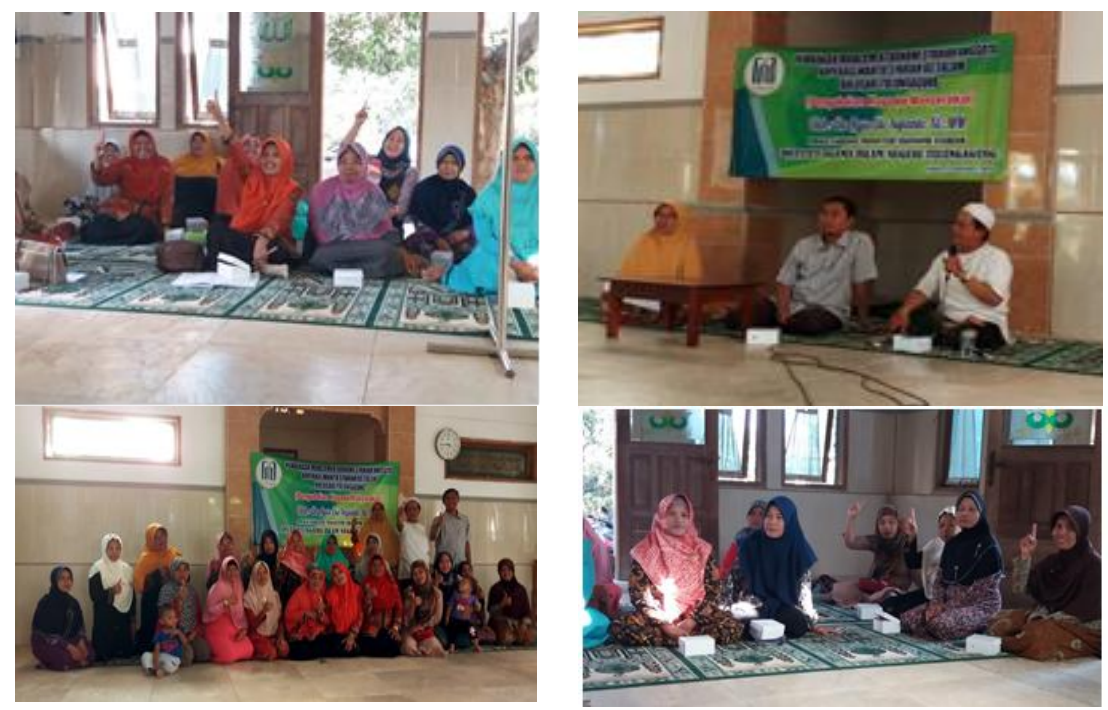

Gambar 5 Pelaksanaan Pembinaan

\section{Diskusi}

Keberhasilan pembinaan pada program pengabdian kepada masyarakat terhadap anggota Kopwan Syariah As Salam Bulusari Tulungagung ini tidak bisa dilepaskan dari peran serta seluruh komponen koperasi yaitu: anggota, pengurus dan pengawas. Berdasar hasil pembinaan dapat dikemukakan bahwa anggota sangat membutuhkan binaan dari perguruan tinggi untuk meningkatkan kualitas usahanya. Mengingat Kopwan As Salam merupakan Kopwan yang secara kelembagaan menggunakan prinsip syariah, maka sudah selayaknya jika koperasi ini secara bertahap juga mengimplementasikan prinsip-prinsip dan nilai-nilai syariah Islam. Konsep yang ditawarkan dalam program ini yaitu pembinaan pada aspek manajemen syariah menggunakan teori yang dikemukakan oleh Amin dan Tim PEBS FEUI (2010). Sedangkan untuk memahamkan tentang akuntansi syariah dalam menyusun perhitungan SHU menggunakan teori yang dikemukakan oleh Kusumawati (2005). Dengan pembinaan manajemen syariah ini diharapkan dapat merubah kelemahan Kopwan Syariah yaitu: (1) semua pilar Kopwan yaitu anggota, pengurus dan pengawas belum sepenuhnya memahami dan mengimplementasikan manajemen syariah dan (2) pengurus belum memahami dan mengimplementasikan akuntansi syariah untuk menyusun laporan SHU, menjadi kekuatan dimana konsep manajemen syariah dan akuntansi syariah secara bertahap diimplementasikan oleh Kopwan Syariah As Salam Bulusari Tulungagung. 


\section{KESIMPULAN DAN SARAN}

Berdasar hasil dan pembahasan dapat disimpulkan:

1. Kopwan Syariah As Salam dalam kegiatan operasionalnya secara implisit sudah mengimplementasikan manajemen syariah dalam bentuk etika bisnis Islam dan TCM;

2. Dalam kaitannya dengan akuntansi syariah, Kopwan Syariah As Salam belum menerapkan prinsip-prinsip akuntansi syariah sebagaimana rekomendasi AAOIFI;

3. Kopwan Syariah As Salam masih menggunakan sistem akuntansi konvensional dalam hal pendapatan bunga;

4. Kopwan Syariah As Salam belum mengeluarkan zakat dari hasil operasional usaha dalam setiap tahun buku.

Secara lebih teknis disarankan kepada beberapa pihak yaitu:

1. Anggota, disarankan untuk meningkatkan kualitas dan kuantitas partisipasinya terhadap Kopwan Syariah As Salam mengingat anggota disamping sebagai pemilik koperasi, juga sebagai pengguna.

2. Pengelola Kopwan Syariah disarankan untuk melakukan perluasan usaha misalnya dengan budidaya ikan dan sayuran dengan sistem MINASA disamping unit usaha utama yaitu simpan pinjam;

3. Dinas Koperasi dan UMKM Tulungagung disarankan untuk memberikan pembinaan dalam kaitannya dengan manajemen syariah dan akuntansi syariah;

4. Perguruan Tinggi disarankan melakukan kerjasama lintas sektoral dengan Dinas Koperasi dan UMKM Tulungagung untuk bersama-sama melakukan kegiatan pengabdian kepada masyarakat pada Kopwan Syariah di Kabupaten Tulungagung;

5. Peneliti selanjutnya disarankan untuk memperluas lokus penelitian dan membuat program pengabdian kepada masyarakat tentang teknis penyusunan laporan keuangan yang sesuai dengan prinsip AAOIFI.

\section{DAFTAR REFERENSI}

[1] Amin, A. R. dan Tim PEBS FEUI, 2010, Menggagas Manajemen Syariah Teori dan Praktik The Celestial Management, Jakarta: Salemba Empat.

[2] Harry A.T. and Ewubare D.B., 2017, The Role of Women Cooperatives in The Economic Development of Rivers State, Academy of Agriculture Journal, Vol. 2 No. 1, pp: 1-4.

[3] Keputusan Gubernur Jawa Timur Nomor 188/ 71 /KPTS/013/2015 Tentang Tim Koordinasi Hibah Perkuatan Permodalan Koperasi/Kelompok Provinsi Jawa Timur Tahun Anggaran 2015.

[4] Keputusan Gubernur Jawa Timur Nomor 188/71/KPTS/013/2015 tentang Tim Koordinasi Hibah Perkuatan Permodalan Koperasi/Kelompok Provinsi Jawa Timur Tahun Anggaran 2015

[5] Koutsou, S., Iakovidou, O. and Gotsinas, N., 2003, Women's Cooperatives in Greece: An Ongoing Story of Battles, Successes and Problems, Journal of Rural Cooperation, Vol. 31 No. 1, pp: 47-57.

[6] Kusumawati, Zaidah, 2005, Menghitung Laba Perusahaan Aplikasi Akuntansi Syariah, Yogyakarta: Magistra Insani Press.

[7] Ngasifudin, M dan Salam, A., 2015, Analisis Akad Pembiayaan Mudharabah dan Implikasinya terhadap Kesejahteraan Anggota dalam Perspektif Ekonomi Syari'ah (Studi Kasus di Kopwan BMT An Nisa Yogyakarta 2013, JESI: Jurnal Ekonomi Syariah Indonesia, Vol. V No. 1, pp: 63-78.

[8] Nurhayati, Sri dan Wasilah, 2015, Akuntansi Syariah di Indonesia, Jakarta: Salemba Empat.

[9] Peraturan Menteri Dalam Negeri Republik Indonesia Nomor 39 Tahun 2012 Tentang Perubahan Atas Peraturan Menteri Dalam Negeri Nomor 32 Tahun 2011 Tentang Pedoman Pemberian Hibah dan Bantuan Sosial yang Bersumber dari Anggaran Pendapatan dan Belanja Daerah.

[10] Rafsanjani, H dan Amin, R., 2017, Peran Koperasi Wanita dalam Membangun Keuangan Inklusif Syariah (Studi Kasus pada Koperasi Simpan Pinjam dan Pembiayaan Syariah Majelis 
DINAMISIA - Jurnal Pengabdian Kepada Masyarakat Vol. 3, No. 2 Desember 2019, Hal. 305-312

Taklim Aisyiyah Sinar Sakinah Mandiri), Jurnal Masharif al-Syariah: Jurnal Ekonomi dan Perbankan Syariah, Vol. 2 No. 2, pp. 1 - 22.

[11] Suaidah, G.Z., 2017, Hubungan antara Pelatihan Menjahit Tingkat Terampil dengan Pembentukan Sikap Wirausaha Bagi Anggota Kopwan (Koperasi Wanita) di Desa Tritunggal Babat Lamongan, Jurusan Pendidikan Luar Sekolah, Vol. 01 No. 01, pp. 0-151.

[12] Suradin, 2018, The Effect of Contextual Teaching and Learning (CTL) Models on learning outcomes of Social Sciences of the material of forms the face of the earth on Class VII of Junior High School, International Journal of Education and Research, Vol. 6 No. 3, pp: 5764.

[13] Suswanto, B; Handoko, W dan Sabiq, A., 2013, Model Community Development Sebagai Strategi Pemberdayaan Berbasis Kearifan Lokal, Jurnal Review Politik, Vol. 03 No 02, pp. 298-312.

[14] Wibowo, M., 2010, Perilaku Konsumen Pengaruhnya terhadap Keputusan Menjadi Nasabah pada Kopwan Syari'ah, Jurnal Dinamika Manajemen, Vol. 4 No. 1, pp: 34-40. 